Still, warns Sanford C. Bernstein's Ronny Gal, if advisory committees become a regular feature of biosimilar reviews, "their composition will have to change to include more protein scientists and animal pharmacologists. If they continue to focus on phase 3 data, it will be tougher for biosimilars to go through."

Sandoz isn't hanging around for the uncertainties to be resolved. Launching this first biosimilar will require the same kind of marketing and educational support as a branded drug, at least for now. Zarzio, as the drug is called in Europe, benefited from such preparedness and is now the region's leading daily filgrastim, with $30 \%$ volume market share. Sandoz believes the US system will eventually adopt products that can save costs. Indeed, FDA's Woodcock's remarks at the committee included likening the potential impact of biosimilars on the healthcare system to that of small-molecule generics.

Zarxio's approval won't open the flood- gates to US biosimilars. The next in line for approval is an infliximab biosimilar made by Incheon, Korea-based Celltrion, with Hospira as the exclusive commercialization partner. It is a copy of Johnson \& Johnson's rheumatoid arthritis drug Remicade and is a far more complex molecule than filgrastim. Also, it lacks the extensive usage data that Sandoz was able to show for Zarxio, which is believed to have reassured the panel, regardless of the strength of the analytical data. Celltrion and Hospira have been selling biosimilar infliximab (as Remsima and Inflectra) in Europe only since September 2013, and only in some Central and Eastern European markets.

Infliximab's review will test how far FDA is prepared to go in allowing extrapolation between indications. Remicade is indicated for eight very different diseases, including rheumatoid arthritis, Crohn's disease and ulcerative colitis. In Europe, the biosimilar was approved for these indications, based on clinical trial data from only two. That might be tougher to achieve in the US, where the drug will face a biosimilar-naive Arthritis Advisory Committee. Torontobased Apotex and Ahmedabad, India-based Intas Biopharmaceuticals with a biosimilar of Amgen's Neulasta (pegfilgrastim) and Hospira with a biosimilar of Amgen's Epogen (epoetin alfa) are the two other known applicants.

Amgen, facing biosimilar assaults on several of its products, announced its own biosimilar development pipeline. Even without that, though, the company will likely use bundling and rebates to leverage its portfolio and market position and defend against any single biosimilar competitor. "It will take time for the first biosimilar to gain share. If Zarxio gets to $30 \%$ in three years, it would be a good result," says Gal.

Melanie Senior London

\title{
Scotts' GM grass grows free from regulation
}

Scotts Miracle-Gro

is developing a turf grass that has been genetically modified (GM) to grow shorter, thicker and darker green than its conventional counterparts. The enhanced grass from the Marysville, Ohio-based

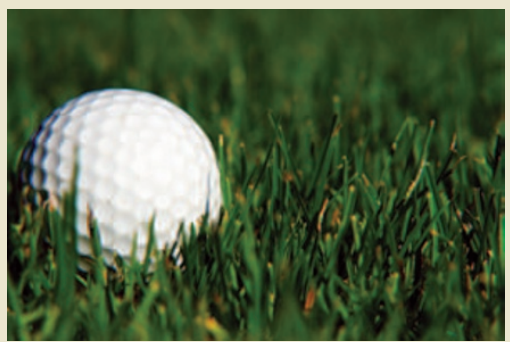

lawn and garden company is yet another novel plant to fall outside the purview of the US Department of Agriculture (USDA), according to documents released in December on the agency's "Regulated Letters of Inquiry" web page.

Scotts says the grass - a tall fescue variety-will require less mowing and fewer nutrient inputs and is also glyphosate tolerant. The genetic material that conferred these traits in the new grass comes from various undisclosed plants and is integrated using established biolistics technology. In this technique, a gene gun bombards cells with heavy metal particles coated with plasmid DNA fired at high speed. Because this transformation technique requires no genetic material from bacteria, viruses or other organisms considered plant pests, the resulting enhanced plants are not subject to oversight by the USDA. Scotts notified the USDA in April 2013 of its intentions to develop the grass. In January 2014 , the federal agency confirmed that the plant was not a regulated article.

Tall fescue is one of at least three GM turf grasses Scotts is developing that doesn't require USDA oversight. The other two-a variety of St. Augustine grass and a variety of Kentucky bluegrass, both engineered to be shorter, thicker, darker green and glyphosate tolerant-were disclosed to the USDA in January 2012.

A concern that some researchers and growers have raised about Scotts' tall fescue is that it can cross with non-GM grass species, potentially causing market disruptions for other growers, particularly those who export to countries where GM plants are not permitted. And unlike for grasses that are subject to USDA's oversight, Scotts doesn't have to publicly disclose whether or not it is conducting field trials or the genes it is using to confer the traits - something that must be done for regulated GM plants before commercialization. Without knowing what the transgenic material is, "we don't even know how to test for it," says Carol Mallory-Smith, a weed scientist at Oregon State University. "It's a big discussion out here in seed country."

Scotts has said it will not grow its GM cultivars in Oregon, where much of the non-GM proprietary tall fescue seed is produced. The company also says it will insert into the trait construct of its GM grasses a genetic marker and can provide sequence information to interested parties, such as non-GM grass producers, weed scientists and governments, who want to identify the GM cultivars, says Bob Harriman, vice president of biotech at Scotts. Harriman says the company's Kentucky bluegrass and St. Augustine grass are in field trials, and tall fescue is still in greenhouse development.

Scotts first tested the regulatory system in 2010 when it argued in a letter to the USDA that another variety of Kentucky bluegrass engineered only for glyphosate tolerance was not subject to the agency's oversight. The agency in July 2011 agreed, making the grass one of the first GM plants to officially skip the agency's regulatory process (Nat. Biotechnol. 29, 772-773, 2011).

The grass set a precedent (Nat. Biotechnol. 30, 215-217, 2012). Since then, various developers have inquired about at least 20 different biotech plants. In all but three of those cases, the agency has agreed that the plants do not require oversight, according to federal documents posted on USDA of those case reviewed by Nature Biotechnology. For example, the USDA has said it has no authority to oversee a GM loblolly pine with increased wood density made by Ridgeville, South Carolina-based Arborgen, and a GM soybean engineered for altered flavonoid profiles made by the University of Georgia in Athens.

Emily Waltz Nashville, Tennessee 